\title{
A procedure for implanting chronic indwelling intraarterial catheters in nonhuman primates
}

\author{
JOSEPH W. TERNES, PIERRE A. CONTI, RONALD N. EHRMAN, \\ and N. WESLEY NORTON \\ Philadelphia Veterans Administration Medical Center, Philadelphia, Pennsylvania
}

\begin{abstract}
A procedure for catheterizing the external iliac artery in nonhuman primates is described. This preparation can be used both for collecting blood samples and for infusing drugs. The preparation is well suited to long-term studies. Our experience indicates that, with appropriate maintenance, these catheters may remain patent for intervals of approximately 12 months.
\end{abstract}

Intravascular catheters are commonly used in behavioral pharmacology experiments with animals. When a catheter is inserted into a blood vessel, a flap membrane begins to form at the tip. Within a short time, this flap interferes with blood withdrawal and eventually interferes with infusion. Patency can be maintained for longer periods, however, with a heparin lock, which slows the formation of a flap membrane. In the event that the catheter becomes occluded, patency can sometimes be restored by instillation or introduction of a clot-dissolving enzyme such as fibrinolysin.

Some catheter sites, such as the saphenous vein, may remain patent for only a few days, whereas other sites, such as the jugular vein, usually remain patent for intervals of approximately 6 to 8 weeks. Shorter catheterpatency durations necessitate switching catheter sites. Recatheterization, however, involves the stress of anesthesia and surgical procedures, as well as the trauma caused by occluding portions of the circulatory system. These factors constitute severe constraints to some short-term procedures and may preclude the use of catheterized animals in long-term experiments.

Unlike venous catheters, arterial catheters tend to remain patent for relatively long time periods. They are usually used for measurement of blood pressure and for blood sampling. They may also be used for infusion. As a route for drug delivery, an arterial catheter is quite similar to the more common venous catheter. Blood flow is toward the heart in the veins, and away from the heart in the arteries. Therefore, in arterial infusion, the drug is distributed to a large peripheral tissue reservoir before it is presented to central receptor sites. Hence, drug effects that are almost instantaneous in venous catheters may be somewhat slower in onset in the arterial preparation. For this reason, somewhat higher

This research was supported by Veterans Administration Medical Research Service Merit Review funds to J. W. Ternes. The author's mailing address is: Philadelphia Veterans Administration Medical Center, University and Woodland Avenues, Philadelphia, Pennsylvania 19104. acute doses are possible with an arterial catheter than with a venous catheter.

This paper describes a procedure for catheterizing the external iliac artery in nonhuman primates. The iliac catheter has been used in our behavioral pharmacology laboratory for the past 18 months. During this period, 14 monkeys have been catherterized: 8 cynomolgus (Macaca fascicularis) and 6 rhesus (Macaca mulata). This site was selected because of the external iliac's size, durability, and central location. When properly prepared, the catheter is completely inaccessible to the animal. Our experience with this preparation indicates that the iliac catheter can be expected to remain patent as a drug-delivery system for periods of 12 months or longer. Patency is dependent, however, on maintenance procedures, such as daily flushing. In our laboratory, the shortest patency duration for the iliac preparation was 3 months. The longest period of patency to date is 14 months. In the latter case, the catheter is still functional.

\section{PROCEDURE}

Table 1 provides a list of suppliers and ordering information for materials that are used in this procedure.

\section{Presurgical Procedures}

(1) Presurgical health exams, including a complete blood count (CBC), are performed within 15 days of surgery.

(2) All animals fast for at least $12 \mathrm{~h}$ prior to surgery to prevent their vomiting while anesthetized and aspirating food particles into the lungs.

\section{Catheter Preparation}

Catheters are prepared in 18-20-in. lengths of Tygon microbore tubing (.050-in. i.d. .090-in. o.d.) and are coated with $2 \%$ TDMAC-Heparin Complex (Table 1) (the solution is drawn through the tubing) and allowed to dry for $72 \mathrm{~h}$. Adequate coating is accomplished 
Table 1

List of Materials

\begin{tabular}{|c|c|c|c|}
\hline Item Name & Manufacturer & Catalog No./Description & Supplier \\
\hline Primate jacket & $\begin{array}{l}\text { Alice King Chatham } \\
\text { Medical Arts } \\
5043 \text { Onaknoll Avenue } \\
\text { Los Angeles, Calif. } 90043\end{array}$ & $\begin{array}{l}\text { Nylon mesh } \\
\text { Small, } 2-4 \mathrm{~kg} \\
\text { Medium, } 4-6 \mathrm{~kg} \\
\text { Latge, } 6-8 \mathrm{~kg}\end{array}$ & $\begin{array}{l}\text { Alice King Chatham } \\
\text { Medical Arts } \\
5043 \text { Onaknoll Avenue } \\
\text { Los Angeles, Calif. } 90043\end{array}$ \\
\hline $\begin{array}{l}\text { Catheter materials } \\
\text { Tygon microbore tubing } \\
\text { (Formulation S } 54 \mathrm{HL} \text { ) }\end{array}$ & $\begin{array}{l}\text { Norton Plastics } \\
\text { and Synthetics } \\
\text { Akron, Ohio } 44200\end{array}$ & $\begin{array}{l}0.05 \mathrm{in} .(1.27 \mathrm{~mm}) \text { i.e. } \times 0.09 \mathrm{in} . \\
(2.27 \mathrm{~mm}) 0 . \mathrm{d} . \times 0.02 \mathrm{in} .(0.51 \mathrm{~mm}) \text { wall } \\
0.04 \mathrm{in} .(1.02 \mathrm{~mm}) \text { i.d. } \times 0.07 \mathrm{in} .\end{array}$ & $\begin{array}{l}\text { Fisher Scientific } \\
585 \text { Alpha Drive } \\
\text { Pittsburgh, Penn. } 15238\end{array}$ \\
\hline Luer stub/tubing adapters & $\begin{array}{l}\text { Clay Adams } \\
\text { Division of Becton } \\
\text { Dickinson \& Co. } \\
\text { Rutherford, N.J. } 07070\end{array}$ & $\begin{array}{l}\text { Intramedic } \\
17 \text { Gauge, No. } 7562^{*} \\
18 \text { Gauge, No. } 7563^{*} \\
19 \text { Gauge, B-D No. } 8209^{*}\end{array}$ & $\begin{array}{l}\text { American Hospital Supply Co. } \\
1450 \text { Waukegan Road } \\
\text { McGaw Park, Ill. } 60085\end{array}$ \\
\hline Injection caps & $\begin{array}{l}\text { Becton-Dickinson } \\
\text { Rutherford, N.J. } 07070\end{array}$ & B-D No. $6974^{*}$ & $\begin{array}{l}\text { American Ho spital Supply Co. } \\
1450 \text { Waukegan Road } \\
\text { McGaw Park, Ill. } 60085\end{array}$ \\
\hline \multirow[t]{3}{*}{ Sutures } & $\begin{array}{l}\text { Ethicon } \\
\text { Somerville, N.J. } 15238\end{array}$ & $\begin{array}{l}00 \text { silk Sutupak (Reg. TM)* } \\
(\mathrm{A} 185 \mathrm{H})\end{array}$ & $\begin{array}{l}\text { American Hospital Supply Co. } \\
1450 \text { Waukegan Road } \\
\text { McGaw Park, Ill. } 60085\end{array}$ \\
\hline & $\begin{array}{l}\text { Ethicon } \\
\text { Somerville, N.J. } 15238\end{array}$ & $\begin{array}{l}000 \text { silk with curved cutting needle } \\
\text { (SA-65-H)* }\end{array}$ & $\begin{array}{l}\text { American Hospital Supply Co. } \\
1450 \text { Waukegan Road } \\
\text { McGaw Park, Ill. } 60085\end{array}$ \\
\hline & $\begin{array}{l}\text { Ethicon } \\
\text { Somerville, N.J. } 15238\end{array}$ & $\begin{array}{l}000 \text { chromic gut with curved taper } \\
\text { needle }(4992 \mathrm{H})^{*}\end{array}$ & $\begin{array}{l}\text { American Hospital Supply Co. } \\
1450 \text { Waukegan Road } \\
\text { McGaw Park, Ill. } 60085\end{array}$ \\
\hline Catheter coating & $\begin{array}{l}\text { Poly sciences, Inc. } \\
\text { Paul Valley Industrial Park } \\
\text { Warrington, Penn. } 18976\end{array}$ & $\begin{array}{l}\text { TDMAC-Heparin Complex } \\
2 \% \text { solution, Catalog No. } 3921\end{array}$ & $\begin{array}{l}\text { Polysciences, Inc. } \\
\text { Paul Valley Industrial Park } \\
\text { Warrington, Penn. } 18976\end{array}$ \\
\hline $\begin{array}{l}\text { Weitlaner self-retaining } \\
\text { retractor }\end{array}$ & $\begin{array}{l}\text { J. Sklar Manufacturing Co. } \\
\text { 38-04 Woodlands Ave., Long } \\
\text { Island City, N.Y. } 11104\end{array}$ & No. $310-351$ surgical wound spreader & $\begin{array}{l}\text { American Hospital Supply Co. } \\
1450 \text { Waukegan Road } \\
\text { McGaw Park, Ill. } 60085\end{array}$ \\
\hline Phisohex antiseptic* & $\begin{array}{l}\text { Winthrop Labs Division } \\
\text { Sterling Drug. Co., } 90 \text { Park } \\
\text { Ave., New York, N.Y. } 10016\end{array}$ & Surgical scrub & $\begin{array}{l}\text { American Hospital Supply Co. } \\
1450 \text { Waukegan Road } \\
\text { McGaw Park, Ill. } 60085\end{array}$ \\
\hline Prepodyne antiseptic* & $\begin{array}{l}\text { Medical Products Divsion } \\
\text { American Sterilizer Co. } \\
2820 \text { W. 23rd Street } \\
\text { Erie, Penn. } 16516\end{array}$ & No. NH003 surgical scrub & $\begin{array}{l}\text { American Hospital Supply Co. } \\
1450 \text { Waukegan Road } \\
\text { McGaw Park, Ill. } 60085\end{array}$ \\
\hline Ketaset (ketamine $\mathrm{HCl}$ ) & $\begin{array}{l}\text { Veterinary Products } \\
\text { Bristol Labs Division } \\
\text { Bristol-Meyers Co. } \\
\text { Syracuse, N.Y. } 13201\end{array}$ & $\begin{array}{l}\text { NDC 0015-2012-10 } \\
\text { anethesia }\end{array}$ & $\begin{array}{l}\text { Frank E. Lentz Co., Inc. } \\
\text { 9226 Keystone Street } \\
\text { Philadelphia, Penn. } 19114\end{array}$ \\
\hline
\end{tabular}

*Generally available from any hospital or veterinary supply house.

within $3 \mathrm{~min}$. Longer residence time results in inflexible tubing, which is undesirable. Subsequently, the catheters are loosely coiled, sealed in cellophane pouches, and gas sterilized.

\section{Surgical Preparation}

The procedure for the surgical preparation is as follows:

(1) The monkey is anesthetized with ketamine hydrochloride (Table 1) at a dosage of $7 \mathrm{mg} / \mathrm{kg} \mathrm{im}$.

(2) Hair is clipped from the abdomen between the sternum and the pubis, and from the back between the shoulder blades, using a No. 40 clipper blade.

(3) The operative sites are disinfected using Phisohex surgical scrub (Table 1).

(4) The animal is transferred from the preparation area to the surgical area and is placed in a supine position, with its arms and legs extended and restrained.

(5) Surgical anesthesia-a halothane and oxygen mixture-is supplied to the animal via pediatric mask. The usual dosage is $1 \%$ halothane (Table 1) per liter of oxygen $\left(\mathrm{O}_{2}\right)$ per minute. The usual flow rate of $\mathrm{O}_{2}$ is 1 liter $/ \mathrm{min}$.

(6) The operative site is further prepared using Prepodyne (Table 1) full strength, followed by $70 \%$ isopropyl alcohol solution.

\section{Surgical Procedure}

(1) The operative area is draped with a sterile fenestrated paper drape.

(2) With a No. 10 scalpel blade, a $5-8-\mathrm{cm}$ incision is made through the skin $5.10 \mathrm{~mm}$ on either side of the 

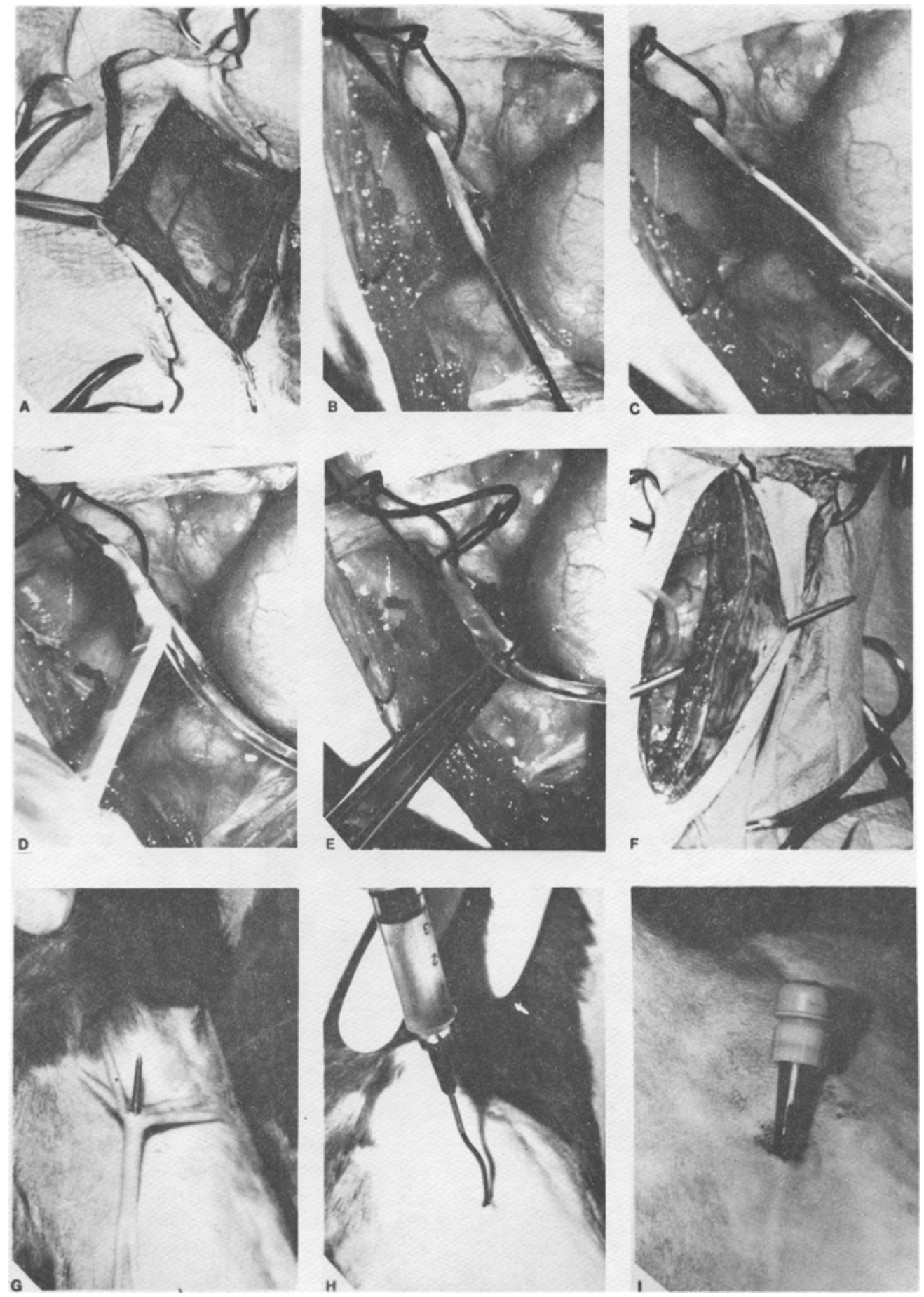

Figure 1. Photographs of the surgical procedure. Plate A-Photograph of the incision prior to the cutting of the peritoneum. Plate B-Photograph of the isolated artery segment elevated away from the abdominal floor. Plate C-Photograph of the iris scissor cutting into the artery. Plate D-Photograph of the catheter introducer with the catheter being inserted into the artery. Plate EPhotograph of the catheter being paseed into the artery with the aid of forceps. Plate F-Photograph of the stainless steel rod piercing the abdominal wall. Plate G-Photograph of the tunneling rod exiting the skin between the shoulder blades. Plate H-Photograph of the externalized catheter with a syringe attached to check for patency. Plate I-Photograph of the Luer stub adaptor and injection cap in which the external catheter terminates. 
midline (depending on whether the right or left iliac artery is to be catheterized) and extending distally from the umbilicus to the pubis.

(3) Underlying muscle and fascia are then separated by blunt dissection. Bleeding is controlled by hemastasis or ligation, using 000 chromic gut as necessary (Figure 1, Plate A).

(4) The peritoneum is cut, and the abdominal cavity is exposed by placement of an Adson or Weitlaner (Table 1) retaining retractor in the incision.

(5) The iliac artery and vein are located, and the artery is exposed by careful blunt dissection.

(6) Three strands of 00 silk suture are placed around the isolated segment of artery. One strand is tightly tied around the distal end of the vessel, and the other two strands are tied loosely around the proximal end of the artery segment.

(7) An 18-20-in. piece of catheter is fitted with a 17-ga Luer stub (Table 1) adaptor and attached to a 5 -cc syringe filled with sterile saline. The free end of the catheter is cut on a bevel, with the point of the bevel rounded off.

(8) The catheter is filled with saline just prior to being inserted into the vessel.

(9) The silk-suture strand around the distal end of the artery segment is tied, occluding the artery.

(10) This strand and one of the two proximally placed strands are grasped by the surgical assistant, and the isolated artery segment is elevated away from the abdominal floor (Figure 1, Plate B).

(11) Upward pressure is applied to the anterior suture strand to occlude all blood flow. An iris scissor is used to make a V-shaped cut in the top of the exposed artery (Figure 1, Plate C).

(12) A catheter introducer is placed in the artery opening, and the catheter is introduced into it (Figure 1, Plate D).

(13) Upward pressure on the proximal suture is reduced enough to permit the catheter to pass (Figure 1, Plate E).

(14) The catheter is advanced up the iliac artery and into the aorta to a point below the bifurcation of the left renal artery. Correct placement may be determined by palpating the tip of the catheter.

(15) The two proximal suture strands are secured over the artery and catheter.

(16) Patency is checked by drawing back on the syringe. Blood return into the syringe indicates that there are no obstructions in the catheter.

(17) Upward pressure on the proximal suture is released and the entry site is inspected for leakage around the catheter. Then, the excess ends of the three retention suture strands are cut.

(18) The retroperitoneum over the catheterized artery is sutured with 000 chromic gut.

(19) The omentum is then returned to its original location, the intestines and bladder are rearranged, and all packing and sponges are removed.

(20) The abdominal wall is punctured at a point on either side of the incision, and the catheter is brought through it (Figure 1, Plate F).

(21) The incision to the abdominal cavity is closed by suturing the peritoneum and fascia with 000 chromic gut.

(22) With a pointed stainless steel rod or a similar tunneling device, the catheter is brought subcutaneously from the abdomen to the exit site, where it is exteriorized. The area between the shoulder blades is generally used, because it is reasonably inaccessible to the animal (Figure 1, Plate G). Care is taken to minimize the size of this catheter tract.

(23) The syringe is then reattached and a check for free blood flow is made through the catheter (Figure 1, Plate $\mathrm{H}$ ). The externalized portion of the catheter is cut such that a $1-\mathrm{cm}$ length protrudes through the skin.

(24) The catheter is flushed with sterile saline, and a 17-ga Luer stub adaptor is attached. An injection cap is then inserted into the adaptor (Figure 1, Plate I).

(25) One or two sutures are placed in the skin to reduce the size of the opening around the external catheter end.

(26) The abdominal incision is closed with 00 silk sutures. Suture ends are trimmed so that the monkey cannot pull at them.

(27) Gas anesthesia is then terminated.

\section{Postoperative Care}

(1) The monkey is fitted with a nylon-mesh restraining vest (Table 1) to prevent the animal from tampering with the external catheter.

(2) Oxygen is administered for 2 to $3 \mathrm{~min}$ in order to speed recovery from the gas anesthesia.

(3) The monkey is then returned to its home cage for recovery, and neither food nor water is provided until the animal is fully conscious (approximately $2 \mathrm{~h}$ ).

(4) Standard monkey chow and water are provided ad lib for the next $48 \mathrm{~h}$.

(5) The catheter is flushed with a saline-heparin solution (100 units of heparin per milliliter at 2-3-day intervals). If daily infusions are performed, the heparin lock is unnecessary.

(6) Skin sutures are removed after 10 days.

(7) Aseptic technique is used in the preparation and infusion of fluids and in drawing blood samples.

(8) Blood samples are collected on a monthly basis and screened for CBC and differential count as a precautionary measure to detect any possible bacterial infection introduced via the catheter.

(9) Any unexplained elevation of white blood cell count should be followed by a blood culture study and appropriate antibiotic therapy.

\section{DISCUSSION}

Postoperative antibiotic therapy is unnecessary if reasonable precautions have been taken to perform aseptic surgery. Although the danger of sepsis is always high with chronic indwelling catheters, it is prudent to 
defer antibiotic treatment until clear indications of infection are present. This reduces the possibility of infection by antibiotic-resistant strains of microorganisms.

A more benign problem that sometimes occurs is stitch removal prior to the incision's healing. Rhesus monkeys are especially prone to picking at their stitches during the first $72 \mathrm{~h}$ after surgery. Since healing is not completed for 8 to 10 days, this can be a problem. The use of the properly fitted nylon vest to prevent access to the exteriorized portion of the catheter can serve to restrict access to the incision site. Further restraint may be necessary by restricting the animal to a restraint chair for 3-5 days to allow the primary wound healing to take place. Our experience indicates that cynomolgus monkeys do not adapt to long periods of chair restraint as well as rhesus monkeys do. Therefore, chair restraint of the cynomolgus should be used as a last resort, and for minimum periods of time.

Sometimes, injection caps on the exteriorized catheter malfunction after several perforations. Close inspection of the rubber cap for leakage at the injection site following infusion is necessary. Injection caps should be replaced routinely after four to five perforations.
Although the iliac catheter is an ideal long-term drug-delivery system, blood samples obtained by drawing back through the same catheter may be contaminated with drug residue from the catheter walls. In order to avoid this problem, it is convenient to perform a dual catheterization procedure in which both the iliac vein and artery are catheterized at the same time. A .040-in. i.d./.070-in. o.d. catheter size is typically used in the vein. This provides two independent routes for drug infusion and for blood drawing. The duration of patency of the venous catheter is limited.

A relatively straightforward surgical procedure has been described for the chronic catheterization of the iliac artery. Any incision into the abdominal cavity should be considered a major surgical procedure and should be attempted only in a properly equipped operating room. The assistance of a veterinarian or surgical technician is advisable. With competent supervision, this technique should be applicable in a variety of behavioral research settings.

(Manuscript received March 4, 1983;

revision accepted for publication August 4, 1983.) 